ТЕХНИКАЛЫҚ ФИЗИКА

ТЕХНИЧЕСКАЯ ФИЗИКА

TECHNICAL PHYSICS

DOI $10.31489 / 2019 \mathrm{Ph} 1 / 73-78$

UDC 620.9

\author{
B.A. Zhautikov ${ }^{1}$, Riad Taha Al-Kasasbeh ${ }^{2}$, A.A. Aikeyeva ${ }^{1}$, A.R. Yerzhanov ${ }^{1}$, A.K. Ayaganov ${ }^{1}$ \\ ${ }^{1}$ Karaganda State Industrial University, Temirtau, Kazakhstan; \\ ${ }^{2}$ Al-Balqa Applied University, Amman, Jordan \\ (E-mail: aikeeva@mail.ru)
}

\title{
Determination of the repulsive force of an electromagnet to provide the necessary clearance from the skip along the entire length of guides of electromagnetic lifting installation
}

\begin{abstract}
The finite element method was chosen as the method of modeling physical fields in electric machines. As the method of modeling physical fields in electric machines a finite element method was chosen. In the article a formula to express an imbalance between the energy stored in a magnetic field and the energy provided by the supplied electric current in this field, under given boundary conditions is used. It has been established that the experiment, planned by the Plakett-Berman matrices, makes it possible to obtain a multifactorial polynomial model of the «lifting vessel - conductor» system, which establishes a relationship between the values of static loads in this system and the operating conditions of the mine lifting systems. The proposed finite element method of considering a permanent magnet as a nonlinear source of a field makes it possible to abandon additional iterations when searching for working points of a magnet. The developed mathematical apparatus takes into account the distribution of magnetization over the cross section of a permanent magnet and identifies non-identical operating points of different magnet elements, which allows to calculate the fields created by the joint action of several current windings and permanent magnets with different orientations in nonlinear and anisotropic media with regard to their mutual influence.
\end{abstract}

Keywords: skip gap, magnetic field, analysis, modeling method, permanent magnet, kinetic energy, potential energy, finite elements method.

The finite element method is based on the calculus of variations [1-11]. In the general case, the variational representation assumes the use of a function based on the Hamilton principle (the principle of least action) [12]: the transition of the system from one state for the time instant t1 to another state for the time instant $\mathrm{t} 2$ occurs so that the minimum of the integral:

$$
\int \mathrm{Qdt} \rightarrow \min ,
$$

where the integrand $Q$ is the force function (Lagrangian) of the given system. In turn, the Lagrangian can be regarded as some functional of the integral type in the volume of the system (object) under consideration. The extremum of this functional is determined by the stationarity condition characterizing the change in the system. The Lagrangian has a direct physical meaning and represents the difference of two terms of the energy type [2]:

$$
\mathrm{Q}=\mathrm{W}_{c}-\mathrm{W}_{p} \text {, }
$$

where $W_{c}$ reflects the kinetic energy, which varies according to the quadratic law as a function of partial derivatives; and $W p$ describes the potential energy. 
Thus, by the theorem on the total potential energy in a state of stable equilibrium, kinematic displacements are allowed that minimize the total potential energy described by such a functional. For the stationary regime and the specific time moment, the Lagrangian of the system $\mathrm{Q} \rightarrow$ min must be minimal.

If the energy density components are known in the two-dimensional problem, then integration over the domain $\mathrm{S}$ is necessary to determine the functional [3]. For example, for an electrostatic field in a twodimensional space (xy) the energy functional has the form:

$$
\mathrm{Q}_{\ni}=\frac{1}{2} \iint\left[\varepsilon\left[\left(\frac{d v}{d y}\right)^{2}+\varepsilon\left(\frac{d v}{d x}\right)^{2}-2 p v\right] d x d y\right.
$$

The generalized functional for stationary thermal, electric, and magnetic fields can be represented in the form [4]:

$$
\mathrm{Q}_{\ni}=\frac{1}{2} \iint_{x y}\left[K\left(\frac{d \varphi}{d y}\right)^{2}+K\left(\frac{d \varphi}{d x}\right)^{2}-2 R \varphi\right] d x d y .
$$

So the functional in the case of a plane-parallel magnetic field has the form [5]:

$$
\begin{gathered}
\mathrm{Q}_{\ni}=\iint_{x y}\left(\int_{0}^{B} H d B-J_{C T} A\right) d x d y=\frac{1}{2} \iint_{x y}\left[\int_{0}^{B^{2}} v\left(B^{2}\right) d B^{2}-2 J_{C T} A\right] d x d y= \\
=\frac{1}{2} \iint_{x y}\left[v\left(\frac{d A}{d y}\right)^{2}+v\left(\frac{d A}{d k}\right)^{2} A\right]-2 J_{C T} d x d y .
\end{gathered}
$$

This function expresses an imbalance between the energy stored in the magnetic field and the energy provided by the supplied electric current in this field, given the boundary conditions.

It can be shown that minimization of such a functional corresponds to a solution of the Poisson equation. We use the positions of the calculus of variations. If the functional is minimal at the point $\mathrm{x} \_$, then $\mathrm{dQ} / \mathrm{dx} \mid \mathrm{x}_{-} 0=0-\mathrm{f}$. This means that the change or the first variation of the functional $\delta \mathrm{Q}$ (otherwise dQ) at this point should be zero. In this case,

$$
\delta Q\left|x_{0}=\left(\frac{d Q}{d x}\right) \delta x\right| x_{0}=0
$$

Then:

$$
\begin{gathered}
\delta Q=\frac{1}{2} \iint_{x y}\left[\frac{d\left(\frac{d A}{d y}\right)^{2}}{d\left(\frac{d A}{d y}\right)} \delta\left(\frac{d A}{d y}\right)+v \frac{d\left(\frac{d A}{d x}\right)^{2}}{d\left(\frac{d A}{d x}\right)} \delta\left(\frac{d A}{d y}\right)--2 J_{C T} \delta A\right] d x d y= \\
=\iiint_{x y}\left[v \frac{d A}{d y} \delta\left(\frac{d A}{d y}\right)+v \frac{d A}{d x} \delta\left(\frac{d A}{d x}\right)-J_{C T} \delta A\right] d x d y=0 .
\end{gathered}
$$

Given that $\delta\left(\frac{d A}{d y}\right)=\frac{d}{d y}(\delta A) u \delta\left(\frac{d A}{d x}\right)=\frac{d}{d x}(\delta A)$ the last relation becomes

$$
\delta Q=\iint_{x y}\left[v \frac{d A}{d y} \frac{d}{d y}(\delta A)+v \frac{d A}{d x} \frac{d}{d x}(\delta A)\right] d x d y-\iint_{x y} j \delta A d x d y=0 .
$$

The Green formula is used for

$$
\iint_{x y}\left[\frac{d U}{d y} \frac{d V}{d y}+v \frac{d U}{d x} \frac{d V}{d x}\right] d x d y=-\iint_{x y} v\left[\frac{d^{2} U}{d y^{2}}+\frac{d^{2} U}{d x^{2}}\right] d x d y+\int_{G} v\left[\frac{d U}{d y} \eta_{x}+\frac{d U}{d x} \eta_{y}\right] d G,
$$

here $G$ is $a$ border area; $\eta x, \eta y$ are the components of the unit external normal $\eta$. 
Then

$$
\delta Q=-\iint_{x y} v \delta A\left[\frac{\partial^{2} A}{\partial y^{2}}+\frac{\partial^{2} A}{\partial x^{2}}\right] d x d y+\int_{0} v \delta \frac{\partial A}{\partial n} d G-\iint_{x y} j_{c m} \delta A d x d y=0
$$

or

$$
\iint_{x y} v \delta A\left[\frac{d^{2} A}{d y^{2}}+\frac{d^{2} A}{d x^{2}}\right] d x d y+\int_{G}-v \delta A \frac{d A}{d n} d G+\iint_{x y} J_{C T} \delta A d x D y=0 .
$$

If the integrals over the domain $(\mathrm{x}, \mathrm{y})$ and the boundary $\mathrm{G}$ are independent, then

$$
\left\{\begin{array}{l}
\iint_{x y} v \delta A\left[\frac{d^{2} A}{d y^{2}}+\frac{d^{2} A}{d x^{2}}\right] d x d y+\iint_{x y} J_{C T} \delta A d x D y=0 \\
\int_{G}-v \delta A \frac{d A}{d n} d G=0
\end{array}\right.
$$

In view of the arbitrariness of the choice, we take $\delta A \neq 0[6]$. Then, for the representation of the continuous computational domain by piecewise linear media, that is, the set of elements with the independence of the magnetic permeability from the $(\mathrm{x}, \mathrm{y})$ coordinates within each element, for the region $\mathrm{S}$ one can write

$$
\frac{d}{d y} \delta\left(\frac{d A}{d y}\right)+\frac{d}{d x}\left(\frac{d A}{d x}\right)+J_{C T}=0
$$

For border G:

$$
\frac{d A}{d n}=0 .
$$

The first relation is the Poisson equation. Since the solution of the problem is considered achieved when such a distribution of the potential $\mathrm{A}$ is found, taking into account the boundary conditions at which the functional is minimal, the principle of the minimum of the total potential energy is mathematically equivalent to the differential equation in the sense that the potential distribution satisfying this equation will also minimize the stored energy [6]. The second relation shows that for MCE the condition of continuity of a function on the boundary is natural and is fulfilled automatically, since the continuity conditions of the field at the boundaries of the elements are satisfied. Taking into account the boundary condition of periodicity and the mixed boundary condition require certain procedures. Physical fields can be nonlinear and anisotropic, both in media properties and in exciting factors. The functional for a two-dimensional magnetic field in the presence of magnetic anisotropy of steel and permanent magnets has the form

$$
\mathrm{Q}_{M}=\frac{1}{2} \iint_{x y}\left\{\left[v_{x}\left(\frac{d \mathrm{~A}}{d y}\right)^{2}+v_{y}\left(\frac{d A}{d k}\right)^{2}\right]-2\left(\frac{d M_{y}}{d x}-\frac{d M_{x}}{d x}+J_{C T}\right)\right\} d x d y .
$$

In this functional, as in the corresponding equation, due to the vector nature of $\mathrm{A}$, the subscript indices of the parameter of the characteristic of the medium in the generalized functional for the electrical equation change places, in comparison with the relations for the scalar functions $\mathrm{T}$ and $\mathrm{V}$.

For a plane-dimensional section of an axisymmetric problem, we introduce a new variable, the stream function $\Psi=$ Ar. Then the differential equation acquires symmetry with respect to the coordinates, and the function takes

$$
\mathrm{Q}_{M}=\frac{1}{2} \iint_{r z}\left\{\left[v_{z}\left(\frac{d \Psi}{d r}\right)^{2}+v_{r}\left(\frac{d \Psi}{d z}\right)^{2}\right] \frac{1}{r}-2 \Psi\left(\frac{d M_{r}}{d z}-\frac{d M_{z}}{d r}+J_{C T}\right)\right\} d z d r .
$$

The functional for a two-dimensional thermal field for anisotropic thermal conductivity, coinciding with the coordinate axes of anisotropy, and taking into account the boundary condition for heat transfer, has the form 


$$
\mathrm{Q}_{T}=\frac{1}{2} \iint_{x y}\left[\lambda_{x}\left(\frac{d \mathrm{~T}}{d x}\right)^{2}+\lambda_{y}\left(\frac{d T}{d y}\right)^{2}-2 P T\right] d x d y+\int_{G}-\left(\frac{1}{2} \alpha T^{2}-P_{G} T\right) d G
$$

ere: $\mathrm{G}$ is the portion of the heat exchange boundary with a cooling medium with a boundary condition characterized by the heat transfer coefficient $\alpha$ and the specific power of the heat sources at the boundary PG. The last integral reflects the retracted / supplied energy across the boundary of the region [13].

For two-dimensional problems of mechanics, from the principle of a minimum of the total potential energy it follows that the transfer functions of equilibrium systems minimize the functional Qc. In this case, the displacement field satisfies the equations of equilibrium and compatibility. The total potential energy is equal to the difference between the internal energy W1 and the work done W1:

$$
\mathrm{Q}_{c}=W_{1}-W_{2}=\frac{h}{2} \iint_{x y}\left[D^{T} \sigma+21^{T} R_{s}\right] d x d y-h \int_{G} 1^{T} R_{G} d G,
$$

where $D$ and $\sigma$ are strains and stresses, respectively $[14,15]$.

Since the deformation is a partial derivative of the displacement vector with respect to the coordinates, and the deformations themselves are determined by stresses, the minimized functional is defined, as for the functionals considered earlier, by the second degree of these partial derivatives (including).

This functional, because of the vector nature of the displacements, differs from the previous functionals, in addition, the components of the displacement vector along the $\mathrm{X}$ and $\mathrm{y}$ axes are interrelated. Consequently, the methods of processing the force field functionals must differ from the methods for processing the functionals of the magnetic, thermal, or electric fields.

\section{Conclusions}

1. Static loads on conductors arise due to the static imbalance of the lifting vessel, the influence of the magnetic field of the electromagnet, and the deviation of the conductors from the vertical. The static imbalance of the lifting vessel arises as a result of the displacement of the center of gravity of the laden vessel relative to the geometric center due to the uneven loading of the rock mass, as well as the eccentric suspension of the skip to the electromagnet.

2. The experiment planned for the Plackett-Berman matrices allows to obtain a multi-factorial polynomial model of the «lifting vessel-conductor» system, which establishes the relationship between the static loads in this system and the operating conditions of mine lifting systems.

3. Analysis of the obtained model shows that in order to reduce static loads on the conductors of the guiding devices, it is necessary:

- adjust the values of the lateral and frontal gaps between the conductors and the guiding devices of the lifting vessel;

- compensate the magnetic field of the electromagnet;

- achieve a decrease in the deviation of the center of gravity of the lifting vessel from its vertical axis; center the vessel.

4. A lifting vessel having increased gaps in the upper guiding devices at great depth provides effective resistance to lateral deflection forces.

5. The electromagnet serves as a damper for static loads on conductors, and its weight must be taken into account when analyzing the forces in the lifting system.

6. Dynamic loads on box-shaped conductors in the lateral and frontal direction are commensurable. The amplitude of loads in the lateral direction is $10 \ldots 15 \%$ less than in the frontal direction.

7. Adjusting the gaps between the guide devices of the lifting vessel and the conductors allows to reduce dynamic loads by $20 \ldots 30 \%$.

8. The number of cycles of oscillations of the conductor after dynamic contact with it of the guide devices of the lifting vessel reaches several tens. This indicates the presence of alternating loads, which leads to an increase in the mechanical fatigue of materials, a decrease in the durability of the elements of the guiding devices.

9. The energy functionals of different physical fields in the finite element method are formulated and justified and their interrelation with differential field equations is shown.

10. The proposed finite-element method of considering a permanent magnet as a nonlinear source of the field makes it possible to abandon additional iterations in the search for magnet work points. The developed 
mathematical apparatus takes into account the distribution of magnetization along the section of a permanent magnet and finds the non-identical operating points of different magnet elements, which allows calculating the fields created by the joint action of several current windings and permanent magnets with different orientations in nonlinear and anisotropic media, taking into account their mutual influence.

\title{
References
}

1 Митчелл Э. Метод конечных элементов для уравнений с частными производными / Э. Митчелл, Р. Уэйт. — М.: Мир, 1981. - $216 \mathrm{c}$.

2 Морозов А.Г. Метод конечных элементов в механике разрушения / А.Г. Морозов. - М.: Наука. — 1980. - 256 с.

3 Норри Д. Введение в метод конечных элементов / Д. Норри, Де Фриз Ж.; пер. с англ. — М.: Мир, 1981. — 304 с.

4 Сабоннадьер Ж.К. Метод конечных элементов и САПР: пер. с фр. / Ж.К. Сабоннадьер, Ж.Л.Кулон. - М.: Мир, 1989. $-190 \mathrm{c}$.

5 Сегерлинд Л. Применение метода конечных элементов / Л. Сегерлинд. - М.: Мир, 1979. — 392 с.

6 Сильвестер П. Метод конечных элементов для радиоинженеров и инженеров-электриков: пер. с англ. / П. Сильвестер, Р.Феррари. - М.: Мир, 1986. — 229 с.

7 Стренг Г. Теория метода конечных элементов / Г. Стренг, Дж. Фикс. - М.: Мир, 1977. — 349 с.

8 Сьярле Ф. Метод конечных элементов для эллиптических задач / Ф. Сьярле. — М.: Мир, 1980. — 512 с.

9 Терзян А.А. Трехмерное магнитное поле линейного индукторного двигателя постоянного тока / А.А. Терзян, А.Д. Джавадян, В.В. Рымша, Е.И. Бородина // Электричество. — 1991. — № 11. — С. 42-46.

10 Sadaragani C. Contributionstothe analysis of magnetic field problemsinelectricalmachines / C. Sadaragani // Chalmers University of Technology, School of electrical energineering. - Technical Report, No. 89, Göteborg, March, 1979. — 152 p.

11 Three-Dimensional Vector Potential Analysis for Machine Field Problems / M.V.K. Chari, A. Konrad, A. Palmo et a1. // ШEE Trans. - 1982. MAG-18. - P. 436-446.

12 Бертинов А.И. Специальные электрические машины. Источники и преобразователи энергии: учеб. пос. для вузов [в 2-х кн.] / А.И. Бертинов, Д.А. Бут, С.Р. Мизюрин, Б.Л. Алиевский, Н.В. Синева / под ред. Б.Л.Алиевского - М.: Энергоатомиздат, 1993. - Кн.1. - 320 с.; - Кн. 2. - 368 с.

13 Демирчян К.С. Машинные расчеты электромагнитных полей: учеб. пос. / К.С. Демирчян, В.Л. Чечурин. - М.: Высш. шк., 1986. - 240 с.

14 Aikeyeva A.A. The research loads on the skip mine and quarry electromagnetic lifting installation / A.A. Aikeyeva, B.A. Zhautikov, F.B. Zhautikov, P.A. Mukhtarova // Bulletin of the University of Karaganda-Physics. — 2015. — No. 3 (79). P. 90-95.

15 Aikeyeva A.A. The research of the «skip - guiding device» system of electromagnetic lifting installation / A.A. Aikeyeva, B.A. Zhautikov, X.S. Rogovaya, F.B. Zhautikov, P.A. Mukhtarova // Bulletin of the University of Karaganda. Series Physics. 2015. 一 № 4 (80). 一 P. 57-61.

\section{Б.А. Жаутиков, Риад Таха Аль-Касасбех, А.А. Айкеева, А.Р. Ержанов, А.К. Аяганов \\ Электрмагнитті көтерме қондырғысының барлық бағыттаушыларының ұзындығы бойынша скиптен қажетті саңылауды қамтамасыз ету үшін электрмагнитті ауыстырудың күшін анықтау}

\begin{abstract}
Электр машиналарында физикалық өрістерді модельдеу әдісі ретінде соңғы элемент әдісі таңдалды. Мақалада магнит өрісінде сақталатын энергия мен осы өрістегі берілген электр тоғымен қамтамасыз етілген энергияның арасындағы шексіз жағдайларды анықтайтын формула қолданылды. ПлакеттБерман матрицаларын қолдану арқылы жоспарланған эксперимент осы жүйедегі статикалық жүктемелердің мәндері мен шахталардың көтеру жүйелерінің жұмыс жағдайлары арасындағы қатынастарды белгілейтін «көтергіш түтікше-өткізгіш» жүйесінің мультифакторлы полиномиялық моделін алуға мүмкіндік береді деп анықталған. Тұрақты магнитті сызықты сызық көзі ретінде қараудың соңғы элемент әдісі магнитті жұмыс нүктелерін іздеу кезінде қосымша итерациядан бастартуға мүмкіндік береді. Дамыған математикалық аппарат тұрақты магниттің көлденең қимасы бойынша магнитизацияның таралуын ескереді және әртүрлі магниттік элементтердің бірдей емес жұмыс нүктелерін анықтайды, бұл олардың өзара әсеріне байланысты сызықты емес және анизотропты орталарда әртүрлі бағыттағы тұрақты ток магниттері мен тұрақты ток магниттерінің бірлескен әрекетімен есептелетін кен орындарын есептеуге мүмкіндік береді.
\end{abstract}

Кілт сөздер: скип өткізгіштігі, магнит өрісі, талдау, модельдеу әдісі, тұрақты магнит, кинетикалық энергия, әлеуетті энергия, соңғы элемент әдісі. 
Б.А. Жаутиков, Риад Таха Аль-Касасбех, А.А. Айкеева, А.Р. Ержанов, А.К. Аяганов

\title{
Определение силы отталкивания электромагнита для обеспечения необходимого зазора от скипа по всей длине направляющих электромагнитной подъемной установки
}

\begin{abstract}
В качестве метода моделирования физических полей в электрических машинах выбран метод конечных элементов. В статье использована формула для выражения дисбаланса между энергией, запасенной в магнитном поле, и энергией, обеспечиваемой подведенным электрическим током в этом поле, при заданных граничных условиях. Установлено, что эксперимент, спланированный по матрицам Плакетта-Бермана, позволяет получить многофакторную полиномиальную модель системы «подъемный сосуд-проводник», которая устанавливает связь величины статических нагрузок в этой системе с условиями эксплуатации шахтных подъемных комплексов. Предложенный конечно-элементный метод рассмотрения постоянного магнита как нелинейного источника поля позволяет отказаться от дополнительных итераций при поиске рабочих точек магнита. Разработанный математический аппарат учитывает распределенность намагниченности по сечению постоянного магнита и осуществляет нахождение нетождественных рабочих точек разных элементов магнита, что позволяет рассчитывать поля, созданные совместным действием нескольких токовых обмоток и постоянных магнитов с различной ориентацией в нелинейных и анизотропных средах с учетом их взаимного влияния.
\end{abstract}

Ключевые слова: зазор скипа, магнитное поле, анализ, метод моделирования, постоянный магнит, кинетическая энергия, потенциальная энергия, метод конечных элементов.

\section{References}

1 Mitchell, \& Ueit, R. (1981). Metod konechnykh elementov dlia uravnenii s chastnymi proizvodnymi [Finite element method for partial differential equations]. Moscow: Mir [in Russian].

2 Morozov, A.G. (1980). Metod konechnykh elementov v mekhanike razrusheniia [Finite element method in fracture mechanics]. Moscow: Nauка [in Russian].

3 Norri, D. (1981). Vvedenie $v$ metod konechnykh elementov [Introduction to the finite element method]. Moscow: Mir [in Russian].

4 Sabonnader, Zh.K. (1989). Metod konechnykh elementov i SAPR [Finite element method and CAD]. Moscow: Mir [in Russian].

5 Segerlind, L. (1979). Primenenie metoda konechnykh elementov [Application of the finite element method]. Moscow: Mir [in Russian].

6 Silvester, P. (1986). Metod konechnykh elementov dlia radioinzhenerov i inzhenerov-elektrikov [Finite element method for radio engineers and electrical engineers]. Moscow: Mir [in Russian].

7 Streng, G. (1977). Teoriia metoda konechnykh elementov [Theory of finite element method]. Moscow: Mir [in Russian].

8 Syarle, F. (1980). Metod konechnykh elementov dlia ellipticheskikh zadach [Finite element method for elliptic problems]. Moscow: Mir [in Russian].

9 Terzyan, A.A., Dzhavadyan, A.D., Rymsha, V.V., \& Borodina, E.I. (1991). Trekhmernoe mahnitnoe pole lineinoho induktornoho dvihatelia postoiannoho toka [Three-dimensional magnetic field of the linear inductor of a motor]. Elektrichestvo, No. 11, $42-46$ [in Russian].

10 Sadaragani, C. (1979). Contributions to the analysis of magnetic field problems in electrical machines. Chalmers university of Technology, School of electrical energineering. Technical Report, N89, Göteborg, March.

11 Chari, M.V.K., Konrad, A., Palmo, A., \& et a1. (1982). Three-Dimensional Vector Potential Analysis for Machine Field Problems. WEE Trans. MAG-18.

12 Bertinov, A.I., But, D.A., Miziytin, S.R., Alievskii, B.L., \& Sineva, N.V. (1993). Spetsialnye elektricheskie mashiny. Istochniki i preobrazovateli enerhii [Special electric machines. Energy sources and converters]. B.L. Alievskoho (Eds.). (In 1-2; In 1, 320; In 2, 368). M.: Enerhoatomizdat [in Russian].

13 Demirchan, K.S., \& Chechurin, V.L. (1986). Mashinnye raschety elektromahnitnykh polei [Machine calculations of electromagnetic fields]. Moscow: Vusshaiia shkola [in Russian].

14 Aikeyeva, A.A., Zhautikov, B.A., Zhautikov, F.B., \& Mukhtarova, P.A. (2015). The research loads on the skip mine and quarry electromagnetic lifting installation. Vestnik Karahandinskoho universiteta. Seriia Fizika - Bulletin of the University of Karaganda. Series Physics, 3 (79), 90-95.

15 Aikeyeva, A.A., Zhautikov, B.A., Rogovaya, X.S., Zhautikov, F.B., \& Mukhtarova, P.A. (2015). The research of the «skip - guiding device» system of electromagnetic lifting installation. Vestnik Karahandinskoho universiteta. Seriia Fizika - Bulletin of the University of Karaganda. Series Physics, 4(80), 57-61. 